\title{
Boko Haram And The Challenges Of Internal Security In Nigeria
}

\author{
Franca Attoh PhD \\ Department Of Sociology \\ University Of Lagos, Akoka-Yaba, Lagos
}

\begin{abstract}
Globally, the subject of national security is fundamental to the progress and development of the nation state. As a result, no nation treats with levity any problem that threatens its national security. The major thrust of this chapter is to assess the actions of Boko-haram and its implications on Nigeria's internal security. It takes a look at why insecurity remains a major challenge in Nigeria despite numerous efforts by the government to ensure the security of lives and property. It interrogates the phenomenon of Boko-haram and the myriad of challenges it poses to internal security in Nigeria. It analyzes the implications of terrorism which range from economic crises to political instability and above all food insecurity resulting in poverty and over two million internally displaced persons especially in the North-east of Nigeria. The author avers that Boko-haram insurgence has a spill-over effect to the countries in the West African sub-region (ECOWAS) thus enlarging the scope of insecurity. The data for the paper were sourced from interviews from military informants and secondary sources such as journals, magazines and internet resources. The author posits that the phenomenon of Boko-haram is as a result of the failure of the social contract and the absence of the process for conflict resolution in the post colonial state. Anchoring the analysis on the theory of Structural Functionalism and Karl Marx's Conflict theory it postulates that the phenomenon of Boko-haram is as a result of the failure of social contract resulting in normlessness and acute deprivation thus culminating in insecurity. It recommends among others, the need to empower the army of the unemployed, equip the security apparatti of the state, arrest and prosecute individuals found guilty of aiding and sponsoring insurgents. And initiate community policing to gather intelligence to stem the rising incidence of internal insecurity.
\end{abstract}

KEYWORDS: Boko-Haram, Internal Security, Terrorism, Insurgence, Food insecurity and Internally displaced persons.

\section{INTRODUCTION}

Terrorism in Nigeria is a phenomenon that dates back to history, and continues to evolve, in terms of structure and function especially when it contains a potent mixture of politics and religion. Since the collapse of the old Soviet Union in 1991 and the end of the cold war, there is a new order of forces along religious divide resulting in a new categorization namely fundamentalist Islam and the conservatives. Fundamentalist Islam which coalesced around countries such as Iran and promoted by the late Osama Bin Laden found sympathy and converts in peripheral states with large population of Muslims such as Nigeria, Algeria and Egypt. The rise of this new ideology has polarized many states in Africa giving rise to violence and anarchy. For instance the Northern part of Nigeria has become a theatre of conflicts and contestation between the Nigerian State and members of the Boko-haram sect. The Bokoharam sect is currently fighting to entrench an Islamic caliphate which incidentally has become a source of destabilization for neigbouring states such as Nigeria and Cameroon.

Since the return to democracy in 1999, Nigeria has witnessed various conflicts ranging from sectarian to ethno-religious crises and currently terrorism in the North-east. Internal security 
of any state in the breach adversely affects the state directly or indirectly ${ }^{1}$. Nigeria is not the only country facing security challenges, especially internal insecurity as some developing and even developed countries are bedeviled with one form of security challenge or the other. Mohammed Marwa who led the Maitasine movement was the first Muslim preacher to engage in the radicalization of Islam in the north in the 1970s and 1980s. He was subsequently exiled by the then President Alhaji Shehu Shagari due to the riots and deaths caused by his doctrine. Many analysts believe that Boko-haram is a reincarnation of Maitasine because of its radical brand of Islam that seems to be patterned after the Taliban in Afghanistan. Boko-Haram, which was designated a terrorist group by the Nigerian Government in 2012 was founded in 2002 as an indigenous Islamic group anchored in a puritanical understanding of Islam that forbids "socalled western lifestyles" and political ideologies. The members of the group do not interact with other Muslims whom they accuse of not practicing Islam in its true essence. The group, which originally was known as 'The Muslim Youth Organization' was led by Mallam Lawal but Mohammed Yusuf became its new leader when Mallam Lawal went for further studies in the year 1999. Yusuf opened up the organization politically by establishing a school for the poor with the intention of helping the governor to establish a Sharia government in Borno State. The organization recruited young Muslims from Niger, Chad and the North-East of Nigeria. Yusuf, a University graduate, anchored his teachings in the denunciation of the evils of corruption and inequality, which engender unemployment and poverty and this endeared him to the poor and marginalized. Initially the organization was not violent and it co-existed with others in Maiduguri for seven years without any incident. This was to end with a string of attacks including the attack on the United Nations building in the federal capital, Abuja beginning in 2010. The attacks by the Boko-haram sect has completely destroyed the economy of the North-east resulting in the internal displacement of over two million persons in Nigeria, three hundred thousand refugees to the Republic of Cameroun and another eighty thousand to Niger Republic and with over 10,849 deaths. $^{2}$

This chapter discusses the phenomenon of Boko-haram and its implications for Nigeria's internal security. In doing this the following questions are raised:

a. What is the new face of Boko-haram?

b. What are the effects of Boko-haram insurgency on Nigeria's security apparatus?

c. What are the effects of Boko-haram on ECOWAS community?

d. What are the challenges of Boko-haram scourge and state response?The chapter is thus divided into five sections. Section one which includes the introduction interrogates the phenomenon of Boko-Haram and its implications for security. Section two discusses extant literature and the concepts of terrorism and security. Section three examines the structural functional theory and Karl Marx's conflict theory as an anchorage for the discourse. Section four discusses the origin of Boko-haram, the new face of Bokoharam, the effects of Boko-haram insurgency on Nigeria's security apparatus, the effects on ECOWAS community and the challenges of Boko-haram's scourge on security and the response of the state while section five concludes the chapter with some recommendations to stem the tide of Islamic fundamentalism.

\section{REVIEW OF EXTANT LITERATURE}

Security simply defined is freedom from risk or danger, safety, fear or anxiety. Paradoxically, security does not connote the absence of conflict but rather the existence of an accepted mechanism for conflict resolution. Security is protection against the breach of the law and enemy attack ${ }^{3}$. It equally connotes the ability of a state to defend itself against any form of aggression, promote its cherished values and enhance the well-being of its people ${ }^{4}$. Security is also defined as a state of being safe and the absence of fear, anxiety, danger, poverty and oppression $^{5}$. It is the preservation of core values and the absence of threats to these values. 
Nigeria, does not possess a set of articulated principles to guide its internal security as the state lacks a well defined ideology. Imobighe, has argued that Nigeria, lacks a clearly defined national security policy despite the periodic reviews of its foreign policy ${ }^{6}$. What exist are mechanisms for handling internal emergencies. The challenge is that each time an internal security situation occurs the state responds by strengthening its coercive apparatti thus further depriving the nation of the opportunity to develop alternative mechanism of resolving such conflicts. Gambo was equally of the opinion that Nigeria is a victim of the coercive and conservative approach to the management of internal security ${ }^{7}$. According to him:

To achieve the goal of internal security, every country invests a lot of money and material. In Nigeria, this has been done by increased budget spending on the military, police and other security agencies whose focus is often than not on ability... and realistic preparedness to counter threats (apparent and real) to internal security. It must be noted that various incidents of internal security breaches have exposed the weakness of the conservative coercive approach in tackling such situations. For instance, one of the most fundamental weaknesses is the lack of synergy between the various security units as each unit tends to operate independent of the others. It is the inability to galvanize these units to collaborate with the citizenry to gather intelligence to prevent security breaches that has exposed the underbelly of the security apparatti in Nigeria.

Fundamentalist Islam is identified by the manner they pursue the Islamic principles. "They seek to achieve their goals by violently confronting the symbols and institutions of state power with the ultimate aim of over throwing it ${ }^{8}$. He further argues that Fundamentalist Islam seeks the application of strict Islamic law, the transformation of Muslim society and a repudiation of European/Western culture and values. The Boko-haram sect typifies Islamic fundamentalism. Some scholars have argued that the rise of fundamentalism is not unconnected with the phenomenon of rising economic hardship and growing poverty in northern Nigeria. This growing Islamic fundamentalism in the north can be located in the regional economic inequalities in Nigeria, fundamentalism is thus a form of protestation for economic marginalization, inequality and injustice ${ }^{9}$. However, the state views sects such as the Bokoharam as a destabilising force and a tool in the hands of demagogues to ferment trouble and violence. Paradoxically, this brand of Islam became popular with young unemployed graduates, and other unemployed youths who abhorred the corruption, weak economic base of the northern economy, poverty, inequality and lack of support for agriculture. They view the political elites as cheats, corrupt and power hungry and sought to violently overthrow the current western and secular order in Nigeria and replace it with an Islamic model and order ${ }^{10}$. Significantly, the terrorist attacks by the Boko Haram sect have resulted in the killing of countless number of innocent people and wanton destruction of properties worth billions of naira through suicide and target bombings. In the words of Albinus:

"Within the last few years, heightened social insecurity in Nigeria has arguably fuelled the crime rate, leaving unpalatable consequences for the nation's economy, the precarious state of the nation's security can be blamed on the handiwork of miscreants and unemployed youth and its growth"11

The above quote gives an insight into the state of insecurity in Nigeria. It is to be noted that in the last few years, heightened social insecurity has arguably fuelled the crime rate, leaving unpalatable consequences for the nation's economy and its growth. Many years back, no one would have thought that terrorism would be so firmly rooted in Nigeria. The situation has worsened from the solitary bomb attempts to a coordinated terror network killing, maiming and kidnapping innocent people. Hitherto it took super intelligence and in-depth knowledge of 
explosive science to make a bomb, today it is as easy as pulling the pin of a grenade. Improvised Explosive Devices (IEDs) are easily made and readily available and used frequently by terrorists.

Whereas government claims the fight to stem the acts of terrorism is improving the citizenry believe there is still a lacuna. .The gap does not lie in the clear understanding of the problem but rather the articulation of appropriate response and solution to plethora of security challenges posed by the Boko-haram terror group. The perception of the general public is that there is a high incapability of government's security apparatus at guaranteeing safety and security to the Nigerian people suffering from Boko-haram attacks.

\section{The Concept of Terrorism}

Many, if not all persons in today's world will agree that the world is not safer place than it was before the second world war. This is as a result of rising terrorist activities exacerbated by the U.S. policy in the Middle East and the upsurge in religious fundamentalism ${ }^{12}$. Abubakar and Ogbeidi, canvassed the fact that factors responsible for terrorism include political agitation, ignorance, deprivation, feelings of oppression, poverty and economic underdevelopment ${ }^{13}$. Often terrorism is perceived as a label used by agents of the state to describe non-state actors in political contestation with a sovereign state. However, some scholars posit that terrorism is violence or threat of violence calculated to create fear and alarm in the victims in a political contestation with the state. The African Union on its part defines terrorism as:

....any act which is a violation of the criminal laws

of a state and which may endanger the life, physical

integrity or freedom of , cause serious injury or death

to any person, any number or group of persons or causes

or may cause damage to public or private property

natural resources, environmental or cultural heritage. ${ }^{14}$

The postulation of Kegley, is that terrorism poses an alarming kind of contemporary violence and the strategy adopted by terrorists embraces the entire gamut of activities committed violently, that draws the attention of the local populace, the government and the world to their cause $^{15}$. The plan of the attack is always to obtain the greatest publicity, choosing targets that symbolize what they oppose. In modern times it has been adopted to mean a wide range of deployment of force largely targeted at civilian populations by disgruntled elements within the society to direct the attention of government to their plight or to force a change of government. The difficulty associated with evolving an acceptable definition of terrorism leads Hoffman to observe that:

If one identifies with the victim of the violence, for example,

then the act is terrorism. If, however, one identifies with the

perpetrator, the violent act is regarded in a more sympathetic

if not positive (or, at the worst, ambivalent) light; and

it is not terrorism ${ }^{16}$.

Scholars such as Kydd and Walter defined terrorism:

"As actions focusing on harming some people in

order to create fear in others by targeting

civilians and facilities or system on which civilians rely"17.

Terrorism is one such reality of our time and the Nigeria state has deployed the coercive apparatti of the state to win the war against terror albeit without success. However, for the scope of this paper Boko-haram is identified as a terrorist group especially since its affiliation 
with the Islamic state in the Levant (ISIL) and the fact that its operations extends to neighbouring states such as Cameroun and the Niger Republic.

\section{The Concept of Security}

Security means safety or freedom from danger; and protection from external attack or infiltration. To further buttress the view of this chapter we look at the definition of national/internal security. Romm had described National security as the lack of danger or risk to held standards, values and ideals and the absence of fear that such values will be attacked now or in the future ${ }^{18}$. Thus, national security is the preservation of the values a nation holds as relates to the defence of its territory from human as well as non-human threats and guides in the pursuit of it national interest in the international system ${ }^{19}$. In a modernizing society, security means development, security is not military hardware, though it may include it; security is not a military force, though it may involve it; security is not traditional military activity, though it may encompass it; security is development, and without development there can be no security. A developing nation that fails to develop cannot remain secure for the intractable reason that its own citizens cannot shed its human nature. National security today is seen as a total security: encompassing security of life and property, security of the economy, security of the economic resources of the country, security of food and raw materials, security of industries, security of the general health of the people, security of the environment and security of national integrity and esteem ${ }^{20}$ The principle of internal security as posited by Ollorwi, are as follows:

1. That conservative and coercive approach to internal security management is not panacea to ensuring stability and law and order within the society but the creation and sustenance of conditions that guarantees fundamental rights of the citizens and removes causes of discontent and internal strife, alleviate socio-economic hardship and inequalities.

2. That the essence of society is the maximization of the general well-being of all people within the society.

3. That internal security is meaningful and succeeds only when it creates conducive atmosphere for the citizenry to pursue their legitimate interests and realize their basic needs.

4. That good governance is the pivot upon which internal security revolves and thrives.

5. That citizen's participation and partnership among the police, public, elected officials, government, and other agencies working together to address crime and safety is key to internal security ${ }^{21}$. But Abubakar and Ogbeidi did argue that the burden of terrorism to the existence and establishment of national security are the need for governments and peoples to manage dissents, incidents and risks in a way that upholds democratic principles ${ }^{22}$. In addition, nation states need to take proactive measures to reduce poverty and engender development which often are reasons given by terror organizations to justify their actions.

\section{THEORETICAL UNDERPINNINGS}

Structural functionalism theory offers some insight to the subject matter because it has a broad perspective. Scholars like Emile Durkheim, Malinoskiwi, and Talcott Parsons among others have contributed to the development of the theory. The theory addresses the society as an organic whole in which each of its institutions work together to maintain the other. Various parts of the society are seen to be closely related and taken together as a complete system. The various security agencies like the Nigeria Police, DSS, NSCDC, NDLEA, Customs and Immigration Services and even the Military work to support the existence of government by providing internal security for the lives and property of the Nigerian people. Therefore lapses in these security apparatti of the state directly or indirectly impact on the general security and 
well being of the people which will in the long run lead to state of insecurity. The terrorist attacks by Boko-haram have led to dramatic consequences resulting in the destruction of lives and properties. This has also affected the effective delivery and efficiency of the several security agencies in the country. Hence, the proper functioning of each part of the society ensures the well being and the survival of the whole society ${ }^{23}$. The implication of the structural functionalism is that internal security can only be guaranteed if there exists inter-agency cooperation with the attendant synergy to ensure that units work in tandem for the overall security of Nigerians.

Karl Marx's conflict theory on the other hand recognizes society as a theatre of contestations between the two main classes in society namely the owners of capital (the property class) and the workers who sell their labour in exchange for wages. According to Marx, the force transforming class membership into a struggle of classes is class interest. He posits that individuals form classes to the extent that their interests engage them in a struggle with the opposing class. At the onset the struggle between classes was confined to the factory floor but with the development of capitalism the disparity between the life conditions of the bourgeoisie and the proletariat crystallizes into a conflict at the societal level. Class consciousness is thus increased, common interests and policies become manifest and the use of and struggle for political power occurs. The distribution of political power is determined by the property class which in turn is used by them to legitimize and protect their property and consequent social relations. The post colonial state is an arena dominated by both the property and intellectual elites and the comprador contractors to the exclusion of the working class and the teeming army of the unemployed. The property class, the intellectual elite, comprador contractors and the military elite have coalesced into the bourgeoisie who control political power and state resources to the exclusion of the working class and the army of the unemployed. The corruption of the political elite with the concomitant inequality and attendant poverty have polarized the two classes in northern Nigeria especially in the north-east of Nigeria, where the majority who are mainly peasants, unemployed or landless proletariats sought liberation from inequality, injustice, corruption, social dislocation and underdevelopment through Jihad. Fundamentalist Islam as typified by Boko-haram view itself as pragmatic and better suited to change the decadent social order.

\section{THE ORIGIN OF BOKO HARAM}

Adibe $^{24}$ had observed that while the popular belief is that it was founded around 2001 or 2002, scholars such as Adeyemi, Abubakari, and Ibrahim, did trace the date to as far back as 1995, and argued that, one Lawan Abubakar, who later left for further studies at the University of Medina, Saudi Arabia, actually founded the Boko Haram sect ${ }^{25}$. Under Abubakar, the sect was known as Sahaba ${ }^{26}$. They started canvassing "true" Islamic law, anti-establishment ideologies, under its leader, Mohammed Ali who was later killed in a shootout with the military in December, 2003. They soon regrouped under a new leader, Mohammed Yusuf who recruited more members, largely from scions of the Northern elite and jobless youths and refugees from Chad. They returned to Maiduguri and started building new structures, offering food, medicine and other benefits to the poor just like the Muslim Brotherhood in Egypt and other parts of the Middle East. The group had, more or less, become a state within a state with its own mosques, cabinet, religious police and farms. They now became known as "the Nigerian Taliban" and reportedly received financial support from Salafist elements in Saudi Arabia as well as wealthy northern Nigerians. In addition, some of their members were known to have had military training in Al-Qaeda training camps in Mauritania, Algeria, Mali and Somalia. 


\section{The New Face of Book Haram}

Civilians and law enforcement personnel had always been their soft targets but now social institutions are also new targets. Rourke, observes that:

War, terrorism and other forms of transnational political

violence are in many ways more threatening today than ever

before as civilian causality has been on the increase ${ }^{27}$.

While the capability of the Boko-haram group was limited to shootings and improvised explosive devices the government did not realize they were re-grouping to employ other tactics to intensify and increase their terrorist attacks. It is important to note that there has been glaring changes in the pattern of Boko-haram insurgency from armed attacks operating with machetes and guns targeting ethnic and religious fault-lines to suicide and target bombings targeting government and international systems as evidenced by the bombing of the Police headquarters and UN building bombing in 2011. The work of Ogbonnaya and Ehigiamuso had shown that the attack launched on the United Nations building in Abuja in 2011 gave the militant group an image akin to Al-Qaeda ${ }^{28}$.

Most recently the sect engaged in various types of kidnapping for ransom and the abduction of the highly media publicized Chibok girls in Borno State. They have reverted to more bombings, both suicide and public; the suicide bombing which occurred in one of the country's institution of higher learning some time ago is another example. In the words of a military personnel who served in Baga:

It is unfortunate that the government under estimated

the capability of the sect for a long time. Rather than an

ill equipped group, we saw a well trained and sophisticated

militia not afraid of regular soldiers and thoroughly abreast

with all the doctrines of reconnaissance ${ }^{29}$.

He was of the view that the hierarchy of the militia must have received the best of trainings from either Libya or Afghanistan. The mastery of weapons especially high caliber weaponry is something that is acquired through rigorous training. He argues that those in charge of the organization must have been undergoing training even before it declared war against the state. In his views Nigeria, should take serious the issue of internal security by deploying intelligence officers to its missions in countries deemed to promote fundamentalism. In addition, the issue of scholarships from such countries should be thoroughly scrutinized as Mujahedeens are recruited under the guise of scholarship.

\section{The Effects Of Boko Haram Insurgency On Nigeria's Security Apparatus}

Challenges facing the security apparatus in Nigeria have led to the damaging consequence of giving the signal to the rest of the international community that Nigeria's military and internal security operatives are not capable of dealing with the Boko-haram scourge. Constant attacks by Boko-haram have seriously undermined Nigeria's Internal security. But perhaps the more dramatic illustration of the lack of confidence in the capacity of the security operatives to provide internal security is the rise of factions of Boko-haram who identify with terrorist groups such as ISIS. Another dramatic illustration of the lack of confidence in the capacity of the police to provide internal security is the rise, activism and proliferation of vigilante groups known as Civilian Joint Task Force (Civilian JTF) in the north-east of Nigeria to assist in the fight against Boko-haram. According to some of the officers who served in Borno state, young civilians were brought in to assist when the military suffered a number of intelligence breaches. They sum it thus:

Serving in Borno was an eye opener for many of us. 
Even though we involved in reconnaissance it was

difficult as many of us are strangers so the issue of trust comes in. You don't even know whether the information been given is correct or if the informant has sympathy for the sect. our men suffered numerous ambush of which some were reported by the media. But the greatest challenge is trust since many of us cannot speak the language. And the fact that that many of the young people were fed up with the system ${ }^{30}$.

It is pertinent to mention that the security operatives have made some remarkable successes but the problem still persists. The failure of security agencies are as a result of a number of factors. Most officers are not trained and equipped with modern security devices and high technological devices required to fight modern day terrorists. One of the officers buttresses this assertion:

The corruption in the society now afflicts the army

It is no longer secret that budgetary allocations are misappropriated. A war of this nature requires the best in terms of weaponry and technology but often we were made to improvise whereas the sect operates with sophisticated equipments. My happiness is that what is hidden is now in the public domain. Do you believe that they have APCs, binoculars, walkie-talkies and yet people don't believe it's a war ${ }^{31}$.

The heads of the country's security agencies have repeatedly claimed that allocations to the sector were insufficient to equip the armed forces and make them operationally efficient to deliver on their mandates. Lack of proper intelligence gathering, leaking of information to the sect by some 'bad eggs' in the ranks and file of the military and lack of proper welfare for security personnel are some of the challenges that hamper the fight against Boko-haram which invariably results in insecurity. He avers that Nigeria has the best security personnel in Africa as attested to each time they took part in peace missions but that politics and corruption will destroy the fighting force if nothing is done to stem the decay.

\section{The Effects On Ecowas Community}

Boko-haram has become a major concern to the Nigerian government and the international community in general since the war against terrorism has now become a universal one and not the concern of any one nation or people. The activities of the sect especially since 2009 have constituted a major security threat to the nation, ECOWAS and the International community at large. Over the years the Nigerian government has enjoyed cordial relationship with governments of neighbouring ECOWAS states. However, the emergence of Boko-haram insurgence has been a source of concern to all ECOWAS member states especially as it portends danger to their own nations. There is the danger that the activities of the sect, if not urgently checked might infiltrate into countries in the West African Sub-region. Such activities are already being felt in neighouring countries of Nigeria such as Cameroon, Chad and Niger Republic. According to some the officers that served in Baga, the greatest danger is in the Lake Chad Basin which is a major food basket. For them:

This is a war, believe it or not, been in Baga has shown that any conflict in Nigeria can destabilize the whole ECOWAS. You need to see how the thriving fishing industry and farming which feeds even our neighbours have been completely destroyed. And the worst is that both soldiers and civilians live in fear. The Mai-tea you see 
in the morning may be one of them. At a time we were

even suspicious of women as we don't know whether

they were used as informants. It is not a tea party at all ${ }^{32}$.

The Nigerian government has been seeking help from whomever and wherever it can get it. ECOWAS, the regional economic community and the African Union (AU), including the UN have all been expressing concern on the deteriorating security situation in Africa's most populous nation. Boko-haram is today, a sprouting menace which is threatening the very survival of Nigeria. In the bid to address the menace of terrorism, the Federal Government engaged development partners, including the United States (US), European Union (EU) and Israel, to step-up the war against terror. Nigeria also got proposals of assistance from Britain, Canada, China, France, Economic Community of West African States (ECOWAS) and the UN, to assist locate the over 276 abducted Chibok secondary school girls who were abducted in Borno State. Even though the sect has released twenty-one of the abducted girls to the government of President Muhammad Buhari, the efforts of these external actors in finding a lasting solution to the problem, is far from being realized. However security strategies by ECOWAS and other external actors are welcomed to help stem the intractable phenomenon.

\section{Boko Haram Scourge And Insecurity In Nigeria: Challenges And Response}

Security is vital for national cohesion, peace and sustainable development. Until recently, Nigeria seemed to have been immune to terrorist activities. Boko-haram scourge remains unyielding to the government who appears helpless in curbing their activities. The dynamics and sophistication of the Boko-haram operations have raised fundamental questions about national security, governance issue and Nigeria's corporate existence. Odo, was of the view that while the security agencies deploy military strategy, the solution to the security challenges in the country ultimately lies in the enthronement of good governance in which opportunities are created for everyone who wants to work to earn a living and poverty is reduced to the barest minimum if not completely eradicated; where there is social justice and equity. This is underscored by the recent global perspective on security as a struggle to secure the most basic necessities of life such as food, health-care, shelter, education, among others. The absence of these basic human securities generates social unrests, which are often exploited by fringe groups such as Boko-haram. Thus, the emergence of Boko-haram insurgency in Nigeria is a direct consequence of the failure of the social contract between the government and the citizenry. The indicators of this failure include the prevalence of abject and dehumanizing poverty; bad governance; high rate of unemployment; hunger and disease; rising tides of social unrest; etc, which have created the breeding ground for the rise and escalation of Boko-haram insurgency.

Nigeria lacks a well-articulated internal security policy in spite of the fact that security has continuously received the greater chunk of the nation's annual budgets. Enormous monetary allocations to the security sector have been made over the years. Amidst claims by Nigerian security agencies that they are being underfunded, budgetary assessment shows that a total N4.62trillion has been allocated to the federal security sector in the past five years ${ }^{34}$. There is also little or no intellectual work devoted to this all important aspect of our national life except intermittent official memoranda, commission reports, and individual write-ups on particular emergency situations. The absence of a workable doctrine for internal security paints a pitiable picture in the face of rising insecurity especially in the north-east which is the epicenter of the conflict. Colossal sums of money are spent as the security sector continues to gulp the highest chunk of the country's expenditure to the detriment of renewing decaying infrastructure and job creation. However, it is unclear as to the gains made as there are no reliable performance reports by the security agencies. The figures for 2011 and 2012 were N920billion and 
N924billion respectively while more than N923billion each was allocated to the sector in 2013 and 2014 and 2015 35 . In spite of this, Nigeria continues to face attacks from the extremist Boko-haram group whose activities have claimed over 11,000 lives in the last five years. The implications of Boko-haram's operation include the slowdown of the country's economic growth and development, worsened unemployment, food scarcity due to the inability of traders to transport food from the North to the South as a result of security challenges, dented Nigeria's public image, increased fear and a false sense of security, recourse to self-help by people and citizens on most occasions such as the emergence of the "Civilian JTF in Borno", loss of life and damage to properties, and so forth ${ }^{36}$. The effects Boko Haram's Insurgency have led to numerous problems for those in the war-torn zone of Northern Nigeria and can simply be summed up as; destruction of lives and properties, creating internally displaced persons, violation of fundamental human rights ,serious threat to democratic consolidation, wastage of huge resources, religious conflicts etc. Government has responded to the insurgency of the Boko-haram sect through the following actions; relocation of the command and control centre of the military to Maiduguri, strengthened the Joint Multi-national Task-Force, dialogue with leaders of the sect and promised them amnesty if the sect lay down their arms, military intervention, executive action such as declaring a state of emergency and appealing for international assistance.

\section{CONCLUSIONS AND RECOMMENDATIONS}

Internal security is the baseline of any nation's security system. Internal security must provide freedom from danger to life and property and ensure the presence of a conducive environment for the masses to pursue their legitimate interests within the society. However, in the case of Nigeria, Internal security is faced with numerous setbacks such as the detonation of IEDs, kidnapping for ransom, abductions and suicide bombings.

Boko-haram has not only been terrorizing the citizens of the northern part of Nigeria but they have succeeded in sowing the seed of fear in the minds of the residents of those states, they have killed, maimed and displaced thousands of people; fathers, mothers, children etc. This has affected deeply the peace and livelihood of those states as a result of the terrorist acts and savage activities of the insurgents. The effects of these acts of terrorism are threats to national security, peace, unity and development of the country. Boko-haram can, at least, be managed if proper strategies are encouraged by the state and put in place. It is expedient for security measures to be deployed to combat and checkmate these insurgents and their activities in order to bring to end or at least minimal level their negative impact on economic development of Nigeria.

\section{Recommendations}

The Boko-haram challenge reflects the deeper crisis that plagues the Nigerian state, in terms of her internal security. The following measures should be put in place if the country is to move from her present state of insecurity to a future near perfect state of security if not perfect.

1. The government should partner with its citizens, diplomats and neighbouring countries for the purpose of information gathering and sharing.

2. Government should seek advice from members of the international community that have dealt with internal security issues, on how to fight and win the war on Bokoharam.

3. Empowering and equipping the military is imperative to getting the right manpower to fight the insurgents.

4. Training and retraining of top officers in the military and other security agencies on the handling, sourcing and management of intelligence reports and also in the operations involved in tackling and combating the insurgents. 
5. Mass education and enlightenment on how to be security conscious and alert in order to create awareness about things happening in the country.

6. Provision of good employment opportunities for the youths in order to discourage them from being used as tools by terrorists and deceitful sponsors of the insurgents.

7. Arresting, investigating and prosecuting individuals found guilty of aiding and sponsoring in any capacity the insurgents.

\section{References}

Okoye, C. (2016). Boko-haram Insurgency in Nigeria: Beyond the Issue of Unity and National Integration. In Open Journal of Philosophy, 6, 311-318. http//dx.doi.org/10.4236/ojpp.2016.64031

Dambazau, A. B. (1999). Criminology and Criminal Justice. Ibadan, Spectrum Books Ltd.

Nwankwo, O.B.C. and Udochuwu, C. M. (2013). Boko-haram Terrorism and Nigeria's Development Vision. IJRSS Vol.3, Issue 2.

Amujiri, B. A. and Agu, S. U. (2012). Threats to Internal Security in Nigeria: An examination of security challenges in Nigeria and its implications. In International Journal of Research in Arts and Social Sciences Vol. 4 . pp.283-296.

Alli, W.O. (2010). The Changing Environment of Nigeria's Foreign Policy. In Osita, C.E (ed). Beyond 50 years of Nigeria's Foreign Policy: Issues, Challenges and prospects. Lagos: Nigerian Institute of International Affairs.

Ibid.

Imobighe T.A (1990). Doctrine for and Threats to Internal Security. In A.E Ekoko and M. A Vogt (Eds) Nigerian Defence Policy: Issues and Problems. Lagos: Malt house Press.

Isa, M. K. (2010). Militant Islamist groups in northern Nigeria. In Okumu, W. and Ikelegbe, A. (eds), Militias, Rebels and Islamist Militants. South Africa, Institute for Security Studies (ISS).

Ibid

Ibid, Isa (2010). p.329

Albinus, C. (2012). Economic Implications of Insecurity. The Punch Newspapers, 4th December, 2012.

Abubakar, MD and Ogbeidi, M.M. (2014). Beyond the Guns: policing Terrorism in a Democratic System. Nigeria, Babcock University Press, Ilisan.

Ibid

Ibid

Kegley, C (2007). World Politics: Trend and Transformation, Eleventh Edition, Thomson Wadsworth.

Hoffman, B. (1998). Inside Terrorism. New York: Columbia University Press.

Alao, D.O. \& Atere, C.O. \& Alao, O. (2012).Boko-Haram Insurgence in Nigeria. Singaporean Journal of Business Economics and Management Studies, 1(4):67-87.

Romm, J.J. (1993). Defining National Security: The Non Military Aspect. New York: Council of Foreign Relations Press.

Folarin, S. (2014). Still on the War on Terror. National Mirror, August 17, 2014.

Osaro, O. (2014).Nigeria Internal Security Landscape http://www.ollorwi.com.ng/ retrieved November 5, 2016.

Ibid.

Ibid, Abubakar and Ogbeidi (2014).

Bothmley, J. (2004). Dictionary of Theories: Barnes and Noble Books, New York

Adibe, J. (2012). Boko Haram: One sect, conflicting narratives. African Renaissance, 9(1).

Ibrahim,H .(2011). Boko-haram claims responsibility. http://www.tribune.com.ng/sat/index.pbp/news/5103boko-haram-claims responsibility.html.

Ibid, Adibe (2012).

Rourke,I.G. ( 2008).Boko Haram leader killed. Daily Trust, July 31 
Ogbonnaya, U.M. and Ehigiamusoe, U.K. (2013) Niger Delta Militancy and Boko-haram Insurgency: National Security in Nigeria. Global Security Studies, Summer.

Interview with a debriefed 35 years old male officer of the Nigerian Army.

Interview with five young male intelligence officers of the Nigerian Army.

Information sourced with middle aged top commander who served in Baga, Borno State.

Interview with three male debriefed officers who served in Baga, Borno state.

Odo, L.U. (2014). Boko-haram and Insecurity in Nigeria: The quest for a permanent solution. In International Multidisciplinary Journal, Ethiopia, Vol. 9(1), Serial No.36.

(http://www.premiumtimesng.com/).

(http://www.premiumtimesng.com/)

Nwankwo, B. C. (2012). Designing Effective Proactive Preventive Security Management Policy at the Local Government Council, paper presented at a workshop on security management alertness at the local government council, Anambra state.

\section{APPENDIX}

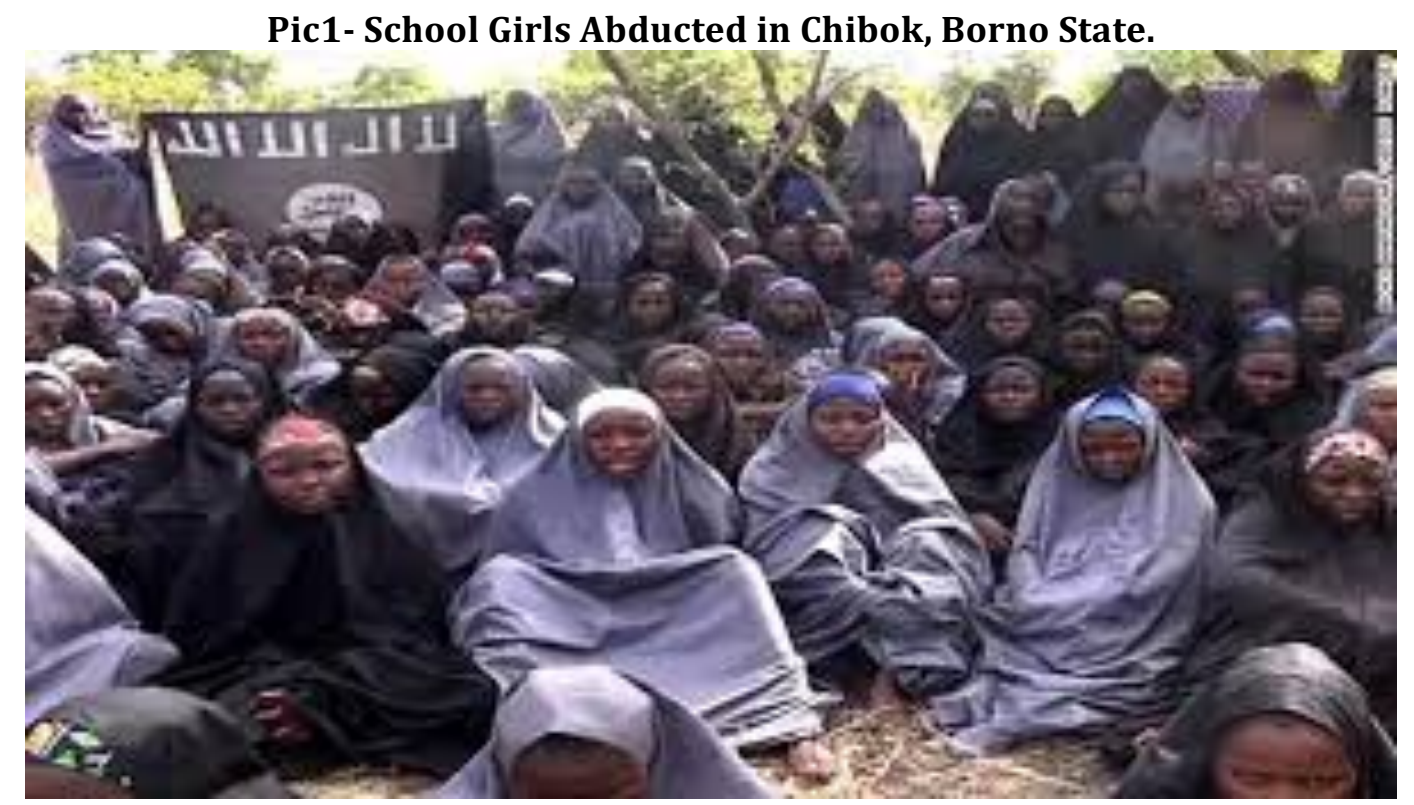

Source: www.premiumtimesng.com/ 
Pic 2- Nigerian troops searching for Boko Haram members in the Forest

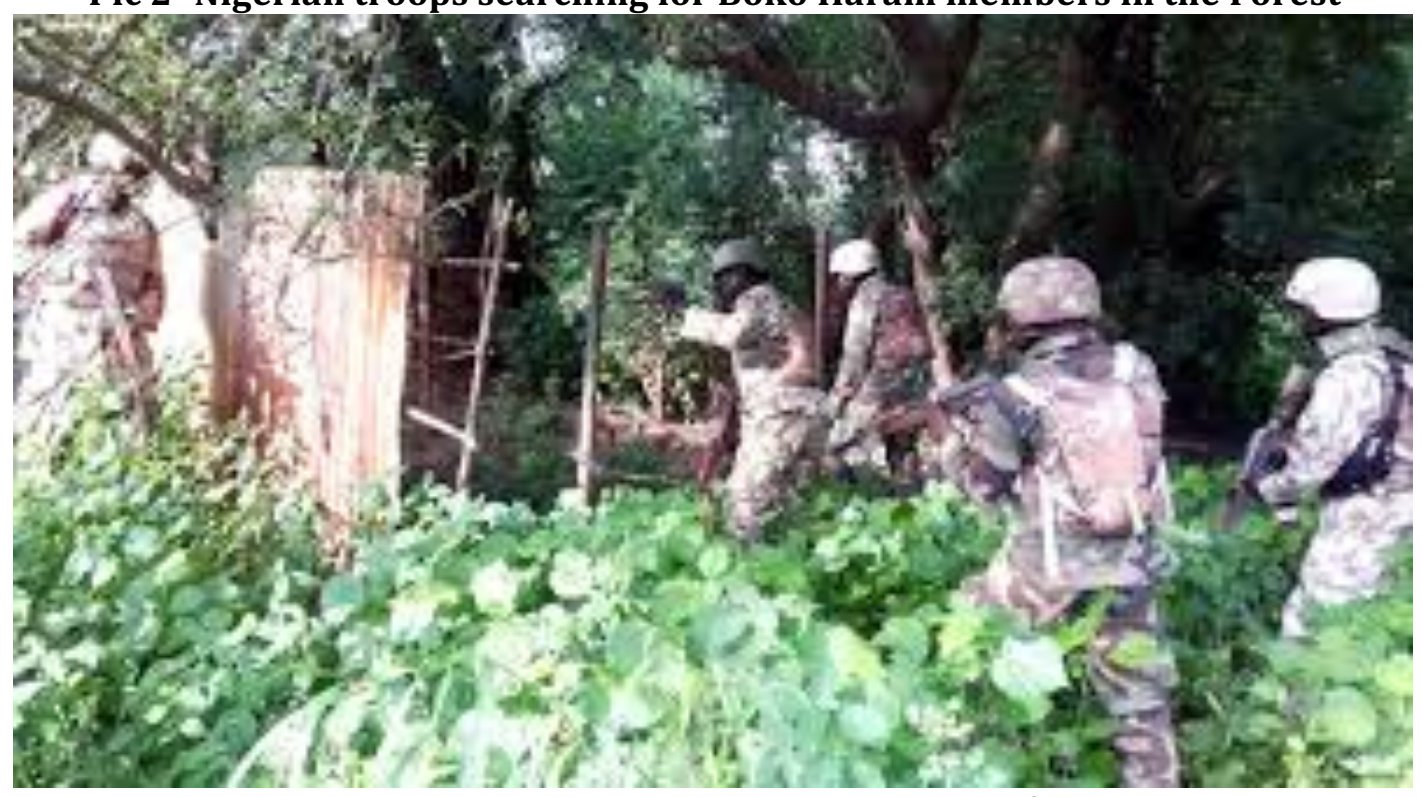

Source: www.premimutimesng.com/

Pic 3- Boko Haram Insurgents about to unleash an attack

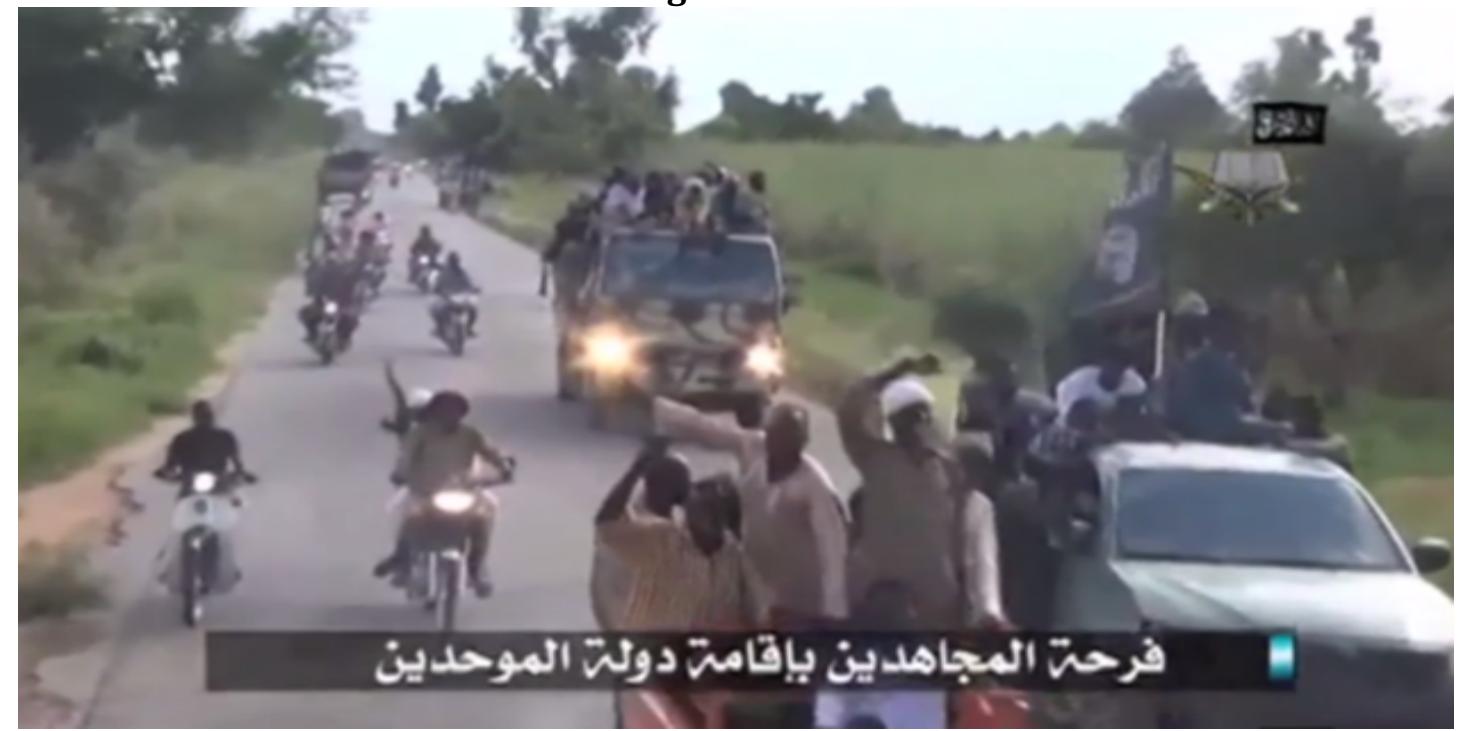

Source: www.premimutimesng.com/ 


\section{Pic 4- Bomb Blast by Boko Haram Insurgents}

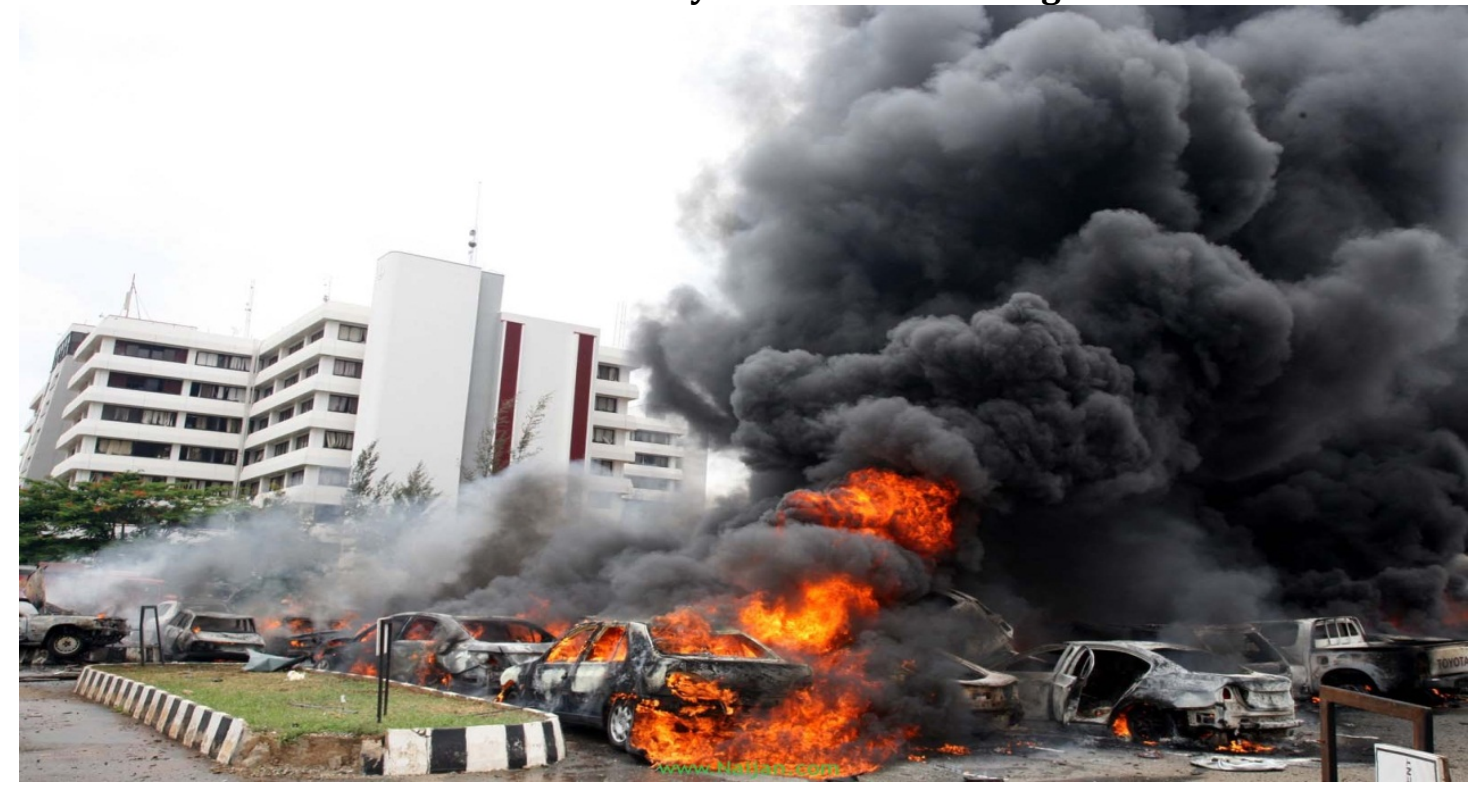

Source: www.nigerianobservernews.com/ 